\title{
OPTIMALISASI PENGEBORAN STERILISASI DAN VERIFIKASI HASIL 3D IP SURVEI DI PARBOTIKAN, MARTABE GOLD MINE, SUMATERA UTARA
}

\author{
Siti Khodijah $^{1)}$, Candra Kusumaa ${ }^{1}$, Henny Purnamasari ${ }^{2)}$ \\ 1) Department Ekplorasi Geologi, Martabe Gold Mine \\ ${ }^{2)}$ Department Project Development, Martabe Gold Mine
}

\begin{abstract}
ABSTRAK
Sejalan dengan peningkatan sumber daya dan cadangan emas-perak di PT. Agincourt Resources (PTAR) dari tahun 2017-2018 dan mengkaji fasilitas penyimpanan tailing yang ada saat ini diperhitungkan tidak mampu menampung peningkatan volume tailing sehingga dilakukan penentuan lokasi yang baru. Pemilihan beberapa lokasi baru untuk fasilitas ini sudah dimulai sejak pertengahan tahun 2018 dan Departemen eksplorasi bekerja sama dengan Departemen project development ditugaskan untuk menyelidiki bahwa daerah yang dipilih adalah lokasi yang sesuai. Pengeboran dan data IP (Induced Polarisation) geofiska, digunakan untuk menentukan apakah lokasi yang diusulkan merupakan lokasi yang steril dari sumber daya mineral ekonomis dan stabil secara geoteknik. Program pengeboran fase pertama sudah selesai pada Q1 tahun 2019, berdasarkan data geology permukaan, geokimia dan geofisika yang sudah ada sebelumnya. Limabelas titik bor dengan total kedalaman $6.802 \mathrm{~m}$ telah dilakukan di daerah rencana dengan ratarata total kedalaman 500 meter. Data geologi, struktur dan geokimia bawah permukaan yang diperoleh dari hasil pengeboran akan dikaji untuk menentukan apakah lokasi yang dipilih tepat dan cocok untuk fasilitas tailing manajemen. Fase pengeboran tahap 2 atau tindak lanjut sedang dilakukan, namun tergantung dari hasil survei IP 3D yang baru saja selesai dan saat ini juga sedang dilakukan pemodelan hasil pembacaan geofisika berupa data resistivitas dan chargeabilitas (jika ada indikasi anomali) di area yang belum dilakukan pengeboran sebelumnya, untuk memastikan bahwa area tersebut steril atau tidak terdapat mineral ekonomis. Ketersediaan data teknis dari program eksplorasi juga dapat digunakan untuk mendukung pekerjaan di departemen lain dan hal ini menguntungkan secara signifikan untuk penghematan biaya serta dapat memastikan bahwa pekerjaan selain geologi tidak mempengaruhi potensi/target eksplorasi di daerah tersebut dan memberikan gambaran untuk perencanaan pengeboran lebih lanjut untuk kondisi geoteknik setempat.
\end{abstract}

Kata Kunci: IP Survei, chargeabilitas, geoteknik, geofisika, mineral

\begin{abstract}
As a consequence of an increase in resources and reserves at the Martabe Gold Mine in 2017-2018 the current tailings management facility will be unable to handle the additional tailings and therefore a new location is being pursued. The selection of several new locations for this facility began in mid-2018 and the exploration department in collaboration with the project development department was tasked with investigating that the area chosen was the appropriate location. Drilling and IP (Induced Polarisation) geophysical data was used to determine if the proposed location is likely to contain any significant economic mineralisation and is geotechnically stable.A first phase drilling program that was based on historical surface geology, geochemical and geophysics data was completed in Q1 of 2019. Fifteen drill holes with total of 6,802m were collared within or proximal to the proposed location and were drilled to an average depth of $500 \mathrm{~m}$. Subsurface geology, structure and geochemical data acquired in the Phase 1 drilling program was reviewed to determine if the area was suitable for facility tailings management. A second or follow up drilling phase is being considered but is dependent on the results of a recently completed $3 D I P$ survey that is currently being modelled which will provide resistivity and chargeability geophysical signatures (if any) over the area not yet drill tested to ensure that the area is sterile of economic
\end{abstract}


mineralisation. The availability of technical data from Exploration programs being made available to other departments can be significant for cost saving measures and ensure that non geological projects do not affect the exploration potential in the district and provide an overview for further drill planning for geotechnical conditions.

Keywords: IP Survey, chargeability, geotechnical, geophysics, mineral

\section{A. PENDAHULUAN}

Tambang emas Martabe terletak sekitar $40 \mathrm{~km}$ tenggara Sibolga dan $2 \mathrm{~km}$ barat laut dari desa Batangtoru, di Sumatera Utara, Indonesia. Tambang ini dioperasikan oleh PT Agincourt Resources (PTAR) dan saat ini memproses 5.8 Mt bijih emas per tahun dengan kuantitas bijih tambang (LOM) yang diperkirakan sekitar 89 Mt (Cadangan per Januari 2019). Kondisi Iklim Martabe adalah iklim tropis dengan suhu dan kelembaban yang relatif tinggi sepanjang tahun. Curah hujan dialami sepanjang tahun dengan musim hujan selama Oktober hingga Desember, dengan curah hujan tahunan berkisar di $\sim 4.500 \mathrm{~mm}$. Tingkat penguapan relatif konsisten sepanjang tahun pada $128 \mathrm{~mm} /$ bulan $(\sim 1.536 \mathrm{~mm}$ per tahun).

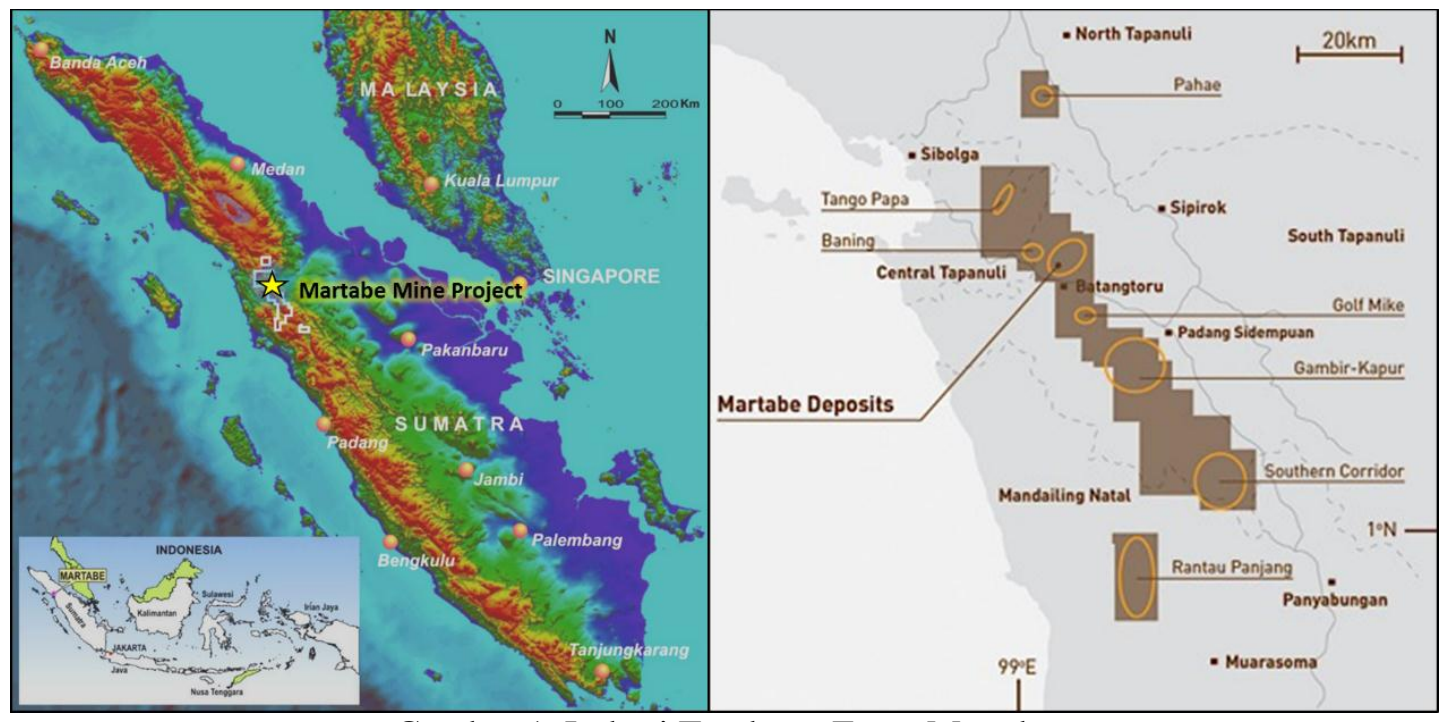

Gambar 1. Lokasi Tambang Emas Martabe

\section{A.1. Latar belakang dan Tujuan}

Adanya penambahan cadangan emas-perak (reserves) pada awal tahun 2019, mengharuskan PT. Agincourt Resources melakukan peninjauan pada semua fasilitas operasi dan produksi yang ada saat ini, untuk memastikan kegiatan penambangan berjalan sesuai dengan rencana tahunan. Salah satu tinjauan yang dilakukan adalah mengenai manajemen fasilitas tailing, dimana dengan cadangan yang ada saat ini, tidak akan mampu lagi menampung proses produksi emas dan perak. Makalah ini akan lebih membahas mengenai pemanfaatan hasil eksplorasi geologi diantaranya pemetaan geologi permukaan, pengeboran eksplorasi, dan pemetaan geofisika, dimana hasilnya bisa dipergunakan oleh departemen lain untuk pertimbangan fasilitas yang diperlukan dikemudian hari.

Langkah awal pemilihan beberapa lokasi fasilitas tailing manajemen sudah dimulai dari pertengahan tahun 2018. Salah satunya adalah daerah prospek Parbotikan yang dinilai cocok untuk failitas tailing manajemen ini dengan pertimbangan luas area bisa mengakomodasi sebagian besar dari tailing yang akan dihasilkan oleh proses produksi emas. Langkah selanjutnya adalah 
memastikan bahwa lokasi tersebut tidak mengandung mineral berharga dan secara geoteknik untuk pondasi tempatan layak dijadikan fasilitas tailing manajemen.

\section{A.2. Pemecahan Masalah}

Atas dasar pertimbangan di atas direncanakanlah pengeboran eksplorasi dengan menggunakan pengeboran batuan inti (diamond drilling/coring), untuk mengetahui kondisi geologi daerah tersebut. Dari batuan inti tersebut selanjutnya dilakukan pengumpulan data geologi sehingga didapatkan data batuan penyusun (lithology), jenis mineral ubahan (alterasi), mineralisasi, dan struktur geologi. Data kandungan mineral logam (emas dan perak) diperoleh dengan mengirimkan sebagian conto batuan inti ke laboratorium untuk dilakukan pengujian mineral logam (assay). Seluruh data tersebut digunakan untuk interpretasi zona mineralisasi dan kandungan logam emasperak.

Untuk melengkapi metode penyelidikan sterilisasi, direncanakan juga dengan memakai survei 3D IP, dimana sudah terdapat data IP konvensional pada daerah tersebut. Induced Polarisasi (IP) adalah metode geofisika yang digunakan secara luas dalam kegiatan eksplorasi mineral dan operasi tambang. Metode resistivitas pada survei IP sering diterapkan pada permukaan tanah dengan menggunakan beberapa elektroda yang terhubung dengan multimeter. Selain data resistivitas, juga diperoleh data chargeabilitas material bawah permukaan. Dari data resistivitas dan chargeabilitas tersebut dilakukan interpretasi terhadap litologi dan alterasi bawah permukaan.

Dari data pemetaan geologi permukaan yang telah dilakukan sebelumnya, pengeboran batuan inti dan survei IP diharapkan dapat menunjang kegiatan sterilisasi lokasi rencana dari kandungan mineral berharga, kondisi geologi dan geoteknik lokasi terpilih.

\section{B. KONSEP PENELITIAN}

\section{B.1. Konsep Umum Sterilisasi}

Penentuan lokasi menjadi hal yang sangat penting untuk memastikan bahwa daerah tersebut tepat secara geoteknikal, tidak berpotensi mengandung mineralisasi secara geologi, dan tidak menimbulkan dampak negatif bagi lingkungan. Beberapa lokasi mulai dipertimbangkan sejak pertengahan tahun 2018, dengan metode pendekatan dari beberapa kajian teknis antara lain studi IP konvensional, pemetaan permukaan dan pengeboran batuan inti.

Fasilitas tailing managemen dalah salah satu peninggalan yang paling nampak dari usaha pertambangan, sehingga setelah penutupan tambang dan rehabilitasi diminta agar tetap stabil dan tidak menimbulkan dampak negatif bagi lingkungan.

\section{B.2. Daerah Kajian}

Salah satu daerah kajian berada di daerah prospek Parbotikan, sekitar 750 meter arah barat laut dari Pit Purnama dan sekitar 900 meter arah barat dari Pit Ramba Joring. Luas wilayah daerah kajian adalah sekitar 280 hektar.

\section{B.3. Pemetaan Geologi Permukaan}

Pemetaan geologi permukaan dilakukan untuk memperoleh data geologi permukaan yaitu berupa sebaran jenis batuan (lithologi), jenis mineral ubahan (alterasi), mineralisasi, dan struktur geologi. Dari data tersebut kemudian akan diperoleh data interpretasi geologi permukaan sebagai dasar untuk melakukan pengeboran eksplorasi guna memperoleh data bawah permukaan.

\section{B.4. Survei IP Konvensional}

Tahanan dan Polarisasi Terinduksi (Induced Polarization/IP) adalah metode survei geofisika yang umum digunakan untuk mengukur sifat kelistrikan batuan bawah permukaan. Untuk pengukuran resestivitas dan chargeabilitas, dilakukan dengan injeksi arus listrik yang terkontrol ke dalam tanah menggunakan dua batang elektroda arus, sehingga memberi energi pada lapisan bawah permukaan 
dan kemudian mengukur tegangan gradien medan potential yang di-induksi diantara dua elektroda penerima yang tidak dapat dipolarisasi. Jarak antara pasangan elektroda saat ini dan pasangan elektroda medan potensial menentukan kedalaman investigasi atau data yang diukur. Tegangan yang dihasilkan sebagai fungsi waktu (time-domain IP / TDIP) direkam secara digital dan dianalisis untuk efek "polarisasi terinduksi". Fase IP yang diukur menunjukkan kemampuan batuan untuk secara singkat menahan muatan listrik setelah tegangan yang dikirim dimatikan.

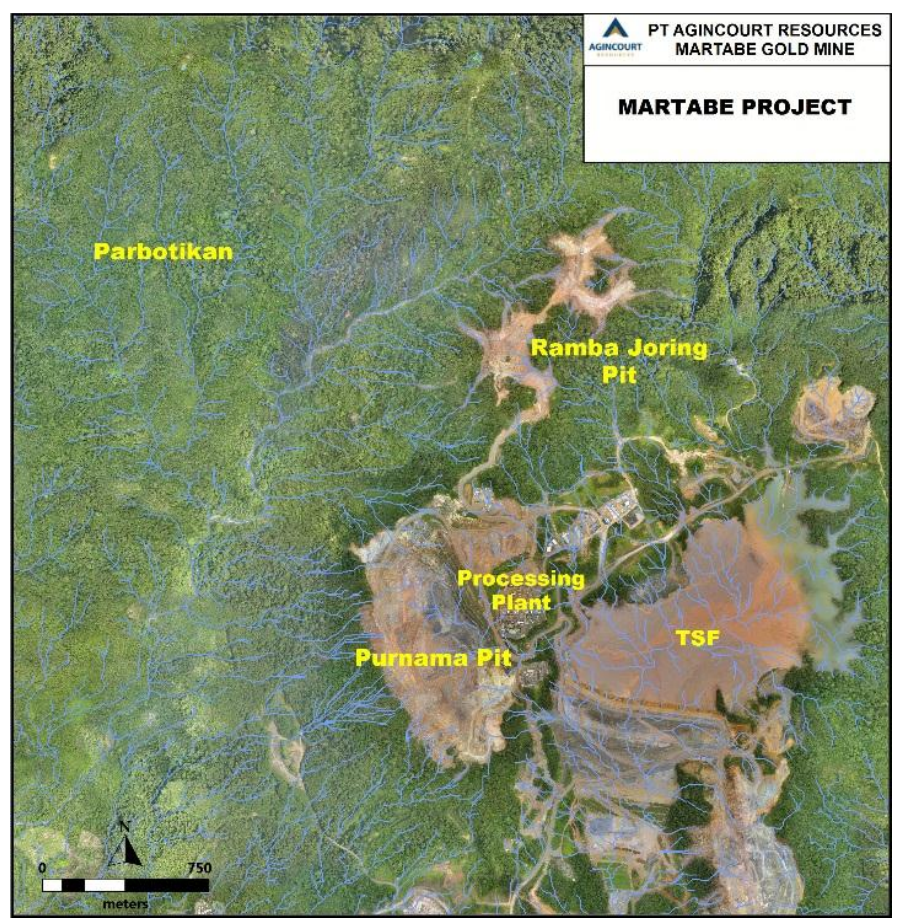

Gambar 2. Lokasi daerah kajian

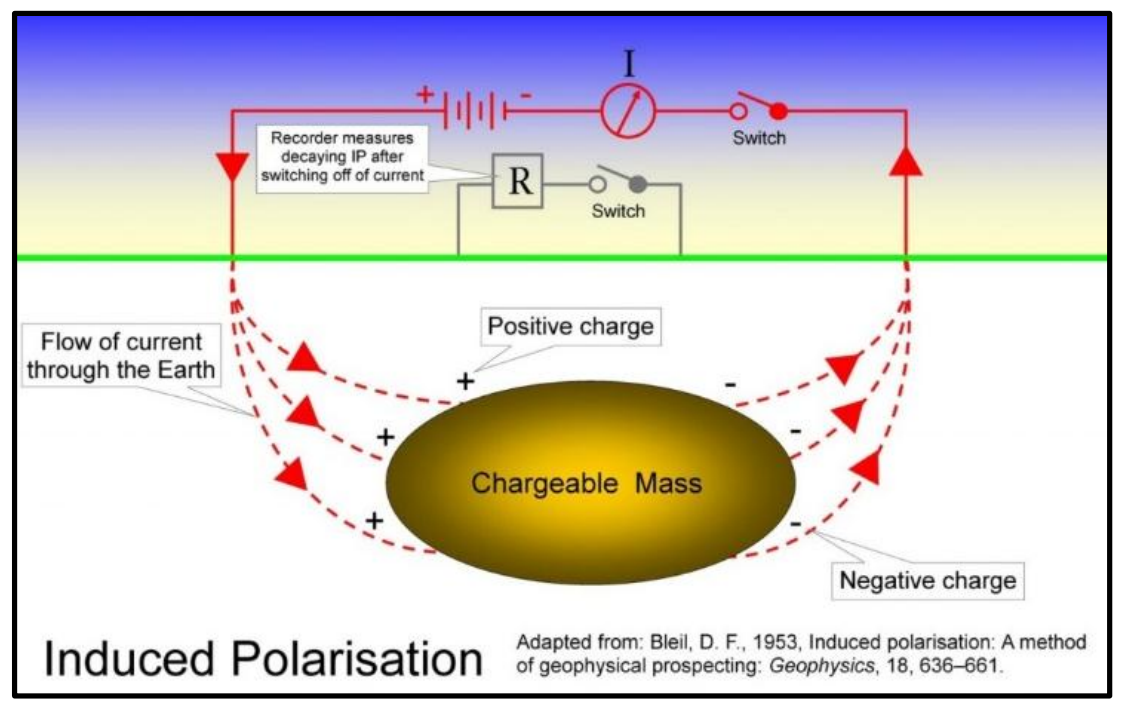

Gambar 3. Skema kerja IP

Pemetaan geofisika terdahulu, dalam hal ini survei IP konvensional sudah pernah dilakukan pada daerah kajian. Data yang ada akan digunakan bersama-sama data pemetaan geologi untuk menentukan lokasi titik pengeboran eksplorasi. Hasil pembacaan data geofisika konvensional tersebut adalah dapat memberikan resolusi yang baik sampai kedalaman 300 meter dibawah permukaan. 


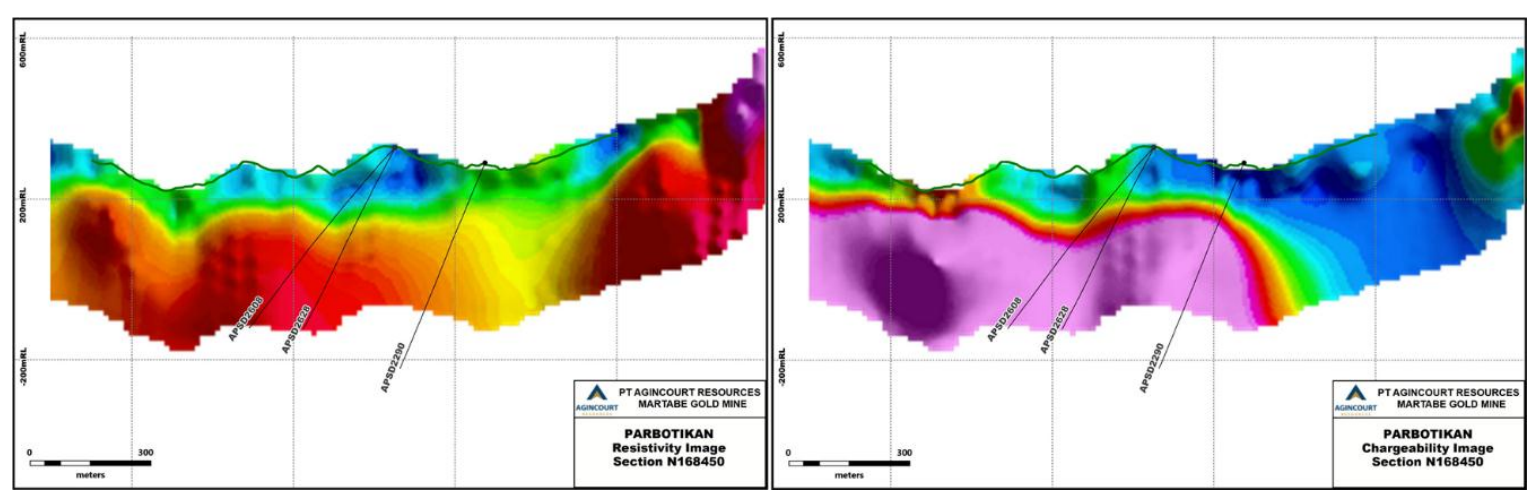

Gambar 4. Penampang resitivitas dan chargeabilitas pada daerah prospek Parbotikan, sayatan profil N168450.

Berdasarkan data pengukuran geofisika, akan diperoleh data resistivitas dan chargeabilitas, dimana secara umum dapat diketahui bahwa:

- Chargeabilitas berkaitan dengan kemampuan batuan atau mineral untuk menyimpan arus listrik pada saat injeksi arus diputus. Nilai chargeabilitas tinggi hampir selalu berhubungan dengan mineral sulfida, yang dipengaruhi oleh porositas, kadar air dan mineral sulfida itu sendiri. Beberapa mineral sulfida yang umum dijumpai adalah pirit, kalkopirit, bornit, kovelit, sfalerit, galena, tenantit dan tetrahidrit.

- Resistivitas berkaitan dengan kemampuan batuan atau mineral untuk menghantarkan arus listrik pada saat listrik diinjeksi. Semakin besar nilai resistivitas suatu bahan maka semakin sulit bahan tersebut menghantarkan arus listrik, begitu pula sebaliknya. Nilai resistivitas dipengaruhi oleh porositas batuan, kadar air, dan mineral. Jika porositas batuan semakin menyempit atau kandungan airnya sedikit maka nilai resistivitasnya akan semakin besar. Batuan yang kompak dan masih tersusun atas mineral-mineral primer (batuan intrusi) serta batuan dengan porositas buruk (silika) akan memeiliki nilai resistivitas yang tinggi.

\section{B.5. Pengeboran Eksplorasi}

Pengeboran eksplorasi dilakukan untuk memperoleh data geologi bawah permukaan dan mengetahui kemenerusan mineralisasi di permukaan (bila terdapat mineralisasi) hingga ke bawah permukaan. Pengeboran eksplorasi ini juga dimaksudkan sebagai pengebroran sterilisasi pada beberapa lokasi rencana fasilitas tailing manajemen apabila kandungan mineral logamnya tidak bernilai ekonomis. Dari hasil pemetaan geologi permukaan dan hasil interpretasi data IP geofisika konvensional, maka dilakukan pengeboran eksplorasi dengan jumlah 15 titik pengeboran dengan total kedalaman 6.802 meter.

\section{B.6. Survei 3D IP (3 Dimensional Induced Polarisation)}

Metode IP yang umum digunakan adalah metode pole-dipole dimana lebih efisien karena hanya membutuhkan pergerakan satu elektroda pemancar dan menghasilkan tegangan penerima yang jauh lebih tinggi.

Metode pengukuran geofisika 3D IP sedikit berbeda dengan pengukuran IP konvensional. Survei ini didesain berdasarkan metode pole-dipole yang telah dimodifikasi, dirancang dengan tujuan untuk mencapai kedalaman yang lebih dalam, operasional lapangan yang efisien, dan tingkat pengumpulan data yang tinggi. Metode ini menggunakan menggunakan transmitter (elektorda pemancar) yang dipasang pada baris yang berselingan dengan receiver (elektroda penerima), dengan spasi antar elektroda berjarak $100 \mathrm{~m}$. Sebuah elektroda pemancar jauh tunggal ditempatkan sekitar $3 \mathrm{~km}$ dari jaringan survei. 


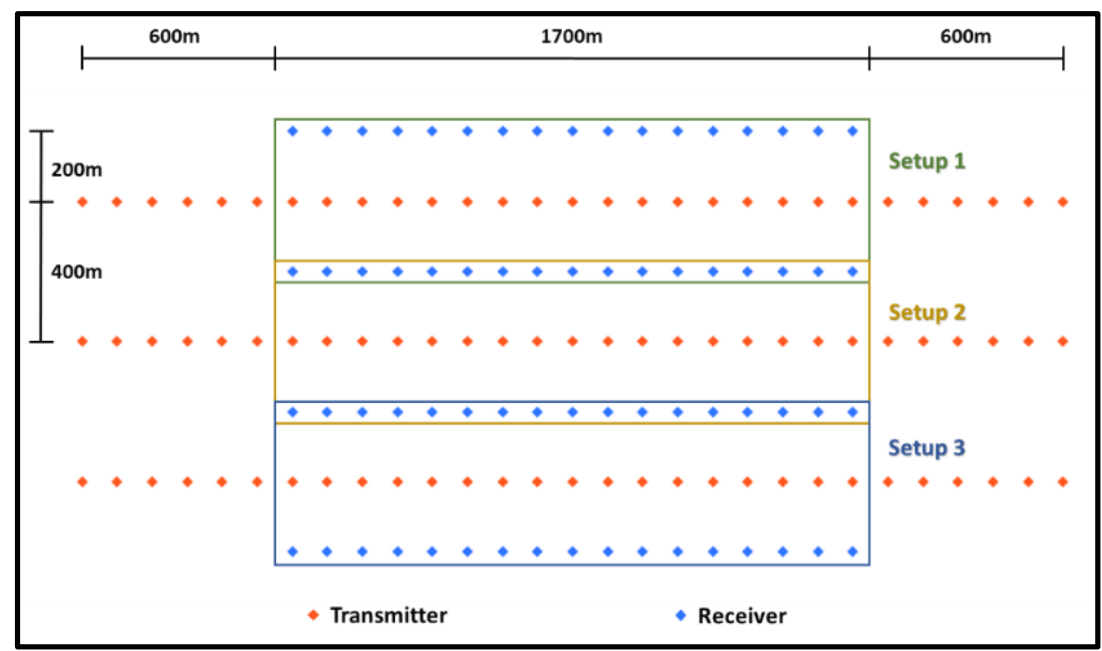

Gambar 5. Konfigurasi elektroda pada survei 3D IP.

Pada saat pengukuran, survei 3D IP ini dapat melakukan perekaman pada 3 baris dalam satu waktu pengukuran dimana arus listrik hanya dialirkan pada baris elektroda pemancar. Setiap baris elektroda penerima akan dilakukan dua kali pengukuran sehingga data yang diperoleh akan menjadi tumpeng tindih, dengan demikian dapat diperoleh hasil perekaman secara 3 dimensi untuk seluruh wilayah yang disurvei.

Efisiensi dari pengukuran menggunakan survei 3D IP ini adalah dapat melakukan pembacaan pada 3 baris dalam satu waktu yang sama dengan kedalaman maksimal mencapai $1000 \mathrm{~m}$ dan resolusi masih sangat baik sampai pada kedalaman $450 \mathrm{~m}$. Semakin dekat jarak antar elektroda maka resolusi dan keakuratan data akan semakin baik.

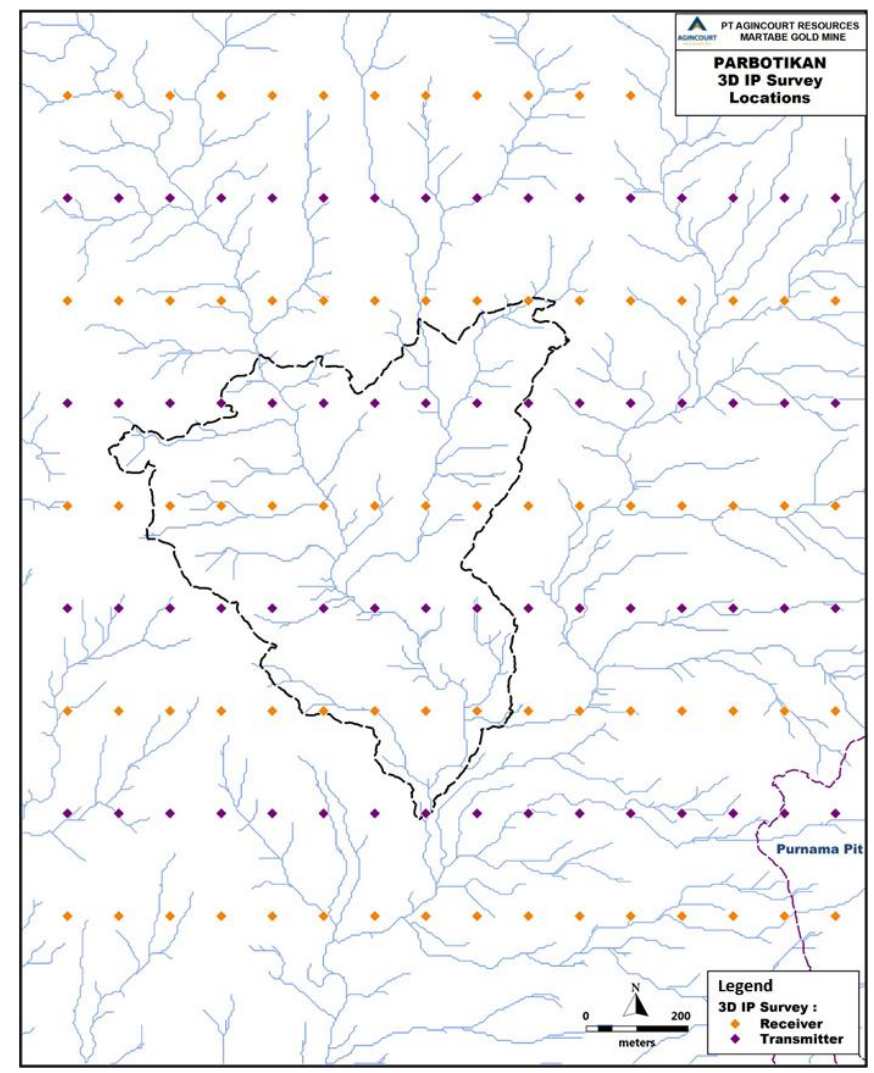

Gambar 6. Rencana pengambilan data geofisika dengan metode survei 3D IP pada daerah kajian. 


\section{HASIL PENELITIAN}

\section{C.1. Geologi Daerah Kajian}

Secara geologi daerah prospek Parbotikan tersusun atas 7 unit batuan yaitu dasit vulkanik, breksi freatomagmatik, diorit intrusi, andesit vulkanik, batupasir - batulanau, dan konglomerat. Sebagian besar unit batuan dasit vulkanik, andesit vulkanik, breksi freatomagmatik, dan batuan sedimen dipotong oleh urat kuarsa.

a. Dasit vulkanik, dicirikan oleh warna abu-abu cerah, tekstur porfiritik, tersusun atas feldspar, hornblenda, biotit, dan kuarsa sebagai fenokris yang tertanam dalam massadasar afanitik.

b. Breksi freatomagmatik, dicirikan oleh kehadiran batuan dasit vulkanik, andesit vulkanik, sedimen karbonat, accretionary lapilli, dan juvenile sebagai fragmen yang tertanam dalam matriks vulkanik. Tekstur batuannya adalah matrix supported, sortasi buruk, dan fragmen monomictic - polymictic. Umumnya unit batuan ini dijumpai pada batuan hasil pengeboran inti.

c. Diorit intrusi, dicirikan oleh warna hijau - hijau cerah, tekstur ekuigranular, tersusun oleh plagioklas, hornblende, kuarsa, dan mineral mafik primer berukuran sampai dengan 1 milimeter. Umumnya memotong unit batuan andesit vulkanik sebagai $d y k e$.

d. Andesit vulkanik, dicirikan oleh warna abu-abu sampai abu-abu kehijauan dan abu-abu gelap, tekstur afanitik dengan ukuran butir sangat halus.

e. Batuan sedimen, terdiri atas 3 jenis batuan yaitu batulanau, batupasir dan konglomerat. Pada bagian selatan daerah kajian dijumpai perlapisan dengan arah baratlaut dan kemiringan perlapisan $40-60^{\circ}$. Unit batuan ini diinterpretasikan saling menjari dengan unit batuan andesit vulkanik.

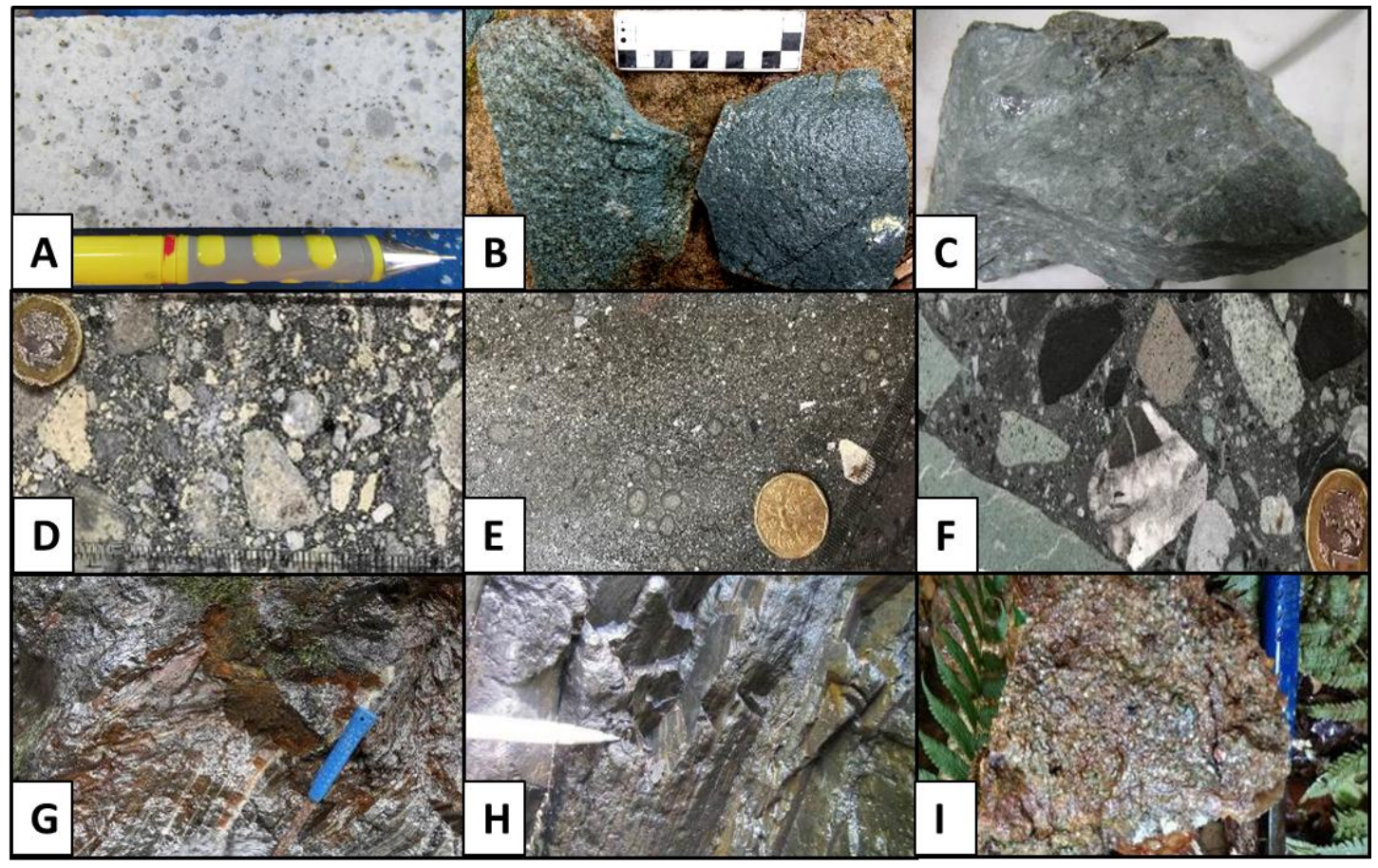

Gambar 7. Unit batuan pada daerah kajian; (A) dasit vulkanik; (B) diorit intrusi; (C) andesit vulkanik; (D-E-F) breksi freatomagmatik dengan berbagai jenis fragmen, (D) tersusun atas fragmen batulanau, kuarsa, andesit vulkanik, dan juvenile (E) tersusun atas fragmen accretionary lapilli, (F) tersusun atas fragmen andesit vulkanik, batulanau, dan kalsit; (G) batulanau; (H) batupasir berselingan dengan batulanau; dan (I) konglomerat yang dominan tersusun atas kuarsa.

Terdapat 3 arah struktur geologi dominan yang berkembang di daerah kajian berdasarkan data geofisika dan pengukuran di permukaan yaitu berarah baratlaut - tenggara, timurlaut - barat daya, 
dan utara - selatan. Adanya struktur geologi ini sangat mempengaruhi pola perkembangan alterasi dan mineralisasi yang berkembang di daerah prospek Parbotikan.

Alterasi yang berkembang di daerah prospek Parbotikan umumnya dikontrol oleh struktur berarah timurlaut-barat daya, terdiri atas alterasi silisik, alterasi argilik, alterasi argilik lanjut, dan alterasi propilitik.

a. Alterasi silisik, umumnya berasosiasi dengan struktur geologi dan sebagai halo pada urat kuarsa, di beberapa tempat juga dijumpai mineral sulfida. Dijumpai pada hampir seluruh unit batuan, dengan ketebalan mm sampai $5 \mathrm{~cm}$ kearah luar dari urat kuarsa.

b. Alterasi argilik, dicirikan oleh kehadiran mineral illit, illit-smektit, illit-klorit, berasosiasi dengan mineral pirit. Umumnya dijumpai pada seluruh unit batuan.

c. Alterasi propilitik, dicirikan oleh kehadiran mineral klorit-karbonatıepidot yang berasosiasi dengan pirit. Dijumpai pada batuan andesit vulkanik dan diorit intrusi.

d. Alterasi argilik lanjut, dicirikan oleh kehadiran mineral dikit-kaolin-pirofilit-silika. Dijumpai pada unit batuan andesit vulkanik dan batulanau, serta dijumpai sedikit pada batupasir dan konglomerat. Umumnya berasosiasi dengan struktur geologi berarah utara - selatan.

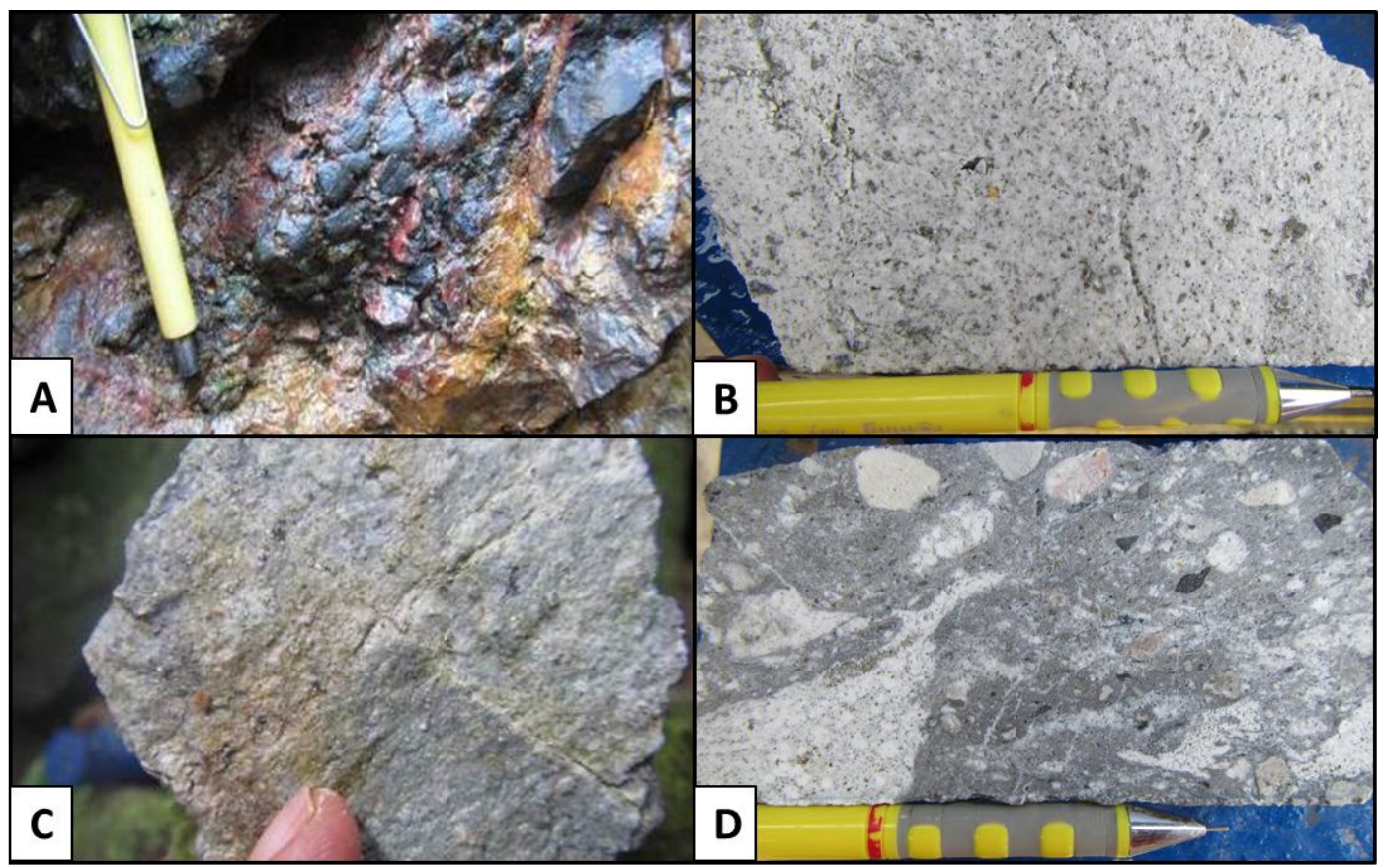

Gambar 8. Alterasi yang berkembang pada daerah kajian; (A) alterasi silisik pada batulanau berasosiasi dengan hematit; (B) alterasi argilik yang terdiri atas mineral illit-smektit; (C) alterasi propilitik pada batuan dasit vulkanik yang tersusun atas mineral klorit-epidot, dipotong oleh urat

\section{C.2. Mineralisasi}

Mineralisasi pada daerah prospek Parbotikan bersifat sporadis dan tidak merata, dimana umumnya berasosiasi dengan struktur geologi dan kehadiran urat kuarsa. Hasil pengujian mineral logam pada conto batuan permukaan umumnya dibawah $0,1 \mathrm{~g} / \mathrm{t}$ emas. Hanya terdapat beberapa conto batuan yang kadar emasnya lebih dari 2,0 g/t emas. Batuan dengan kadar emas yang cukup tinggi ini dijumpai pada urat kuarsa atau breksi freatomagmatik dengan alterasi silisik dan berasosiasi dengan mineral sulfida.

Mineral sulfida pada daerah kajian didominasi oleh mineral pirit, dicirikan dengan ukuran halus sampai dengan sangat halus $(<1 \mathrm{~mm})$, mengisi rekahan dan sebagai disseminated, dan berasosiasi dengan mineral illit. Pada urat kuarsa, di beberapa lokasi juga dijumpai berasosiasi dengan kovelit, sfalerit, dan galena, serta sedikit malakit, tenantit dan tetrahidrit. 


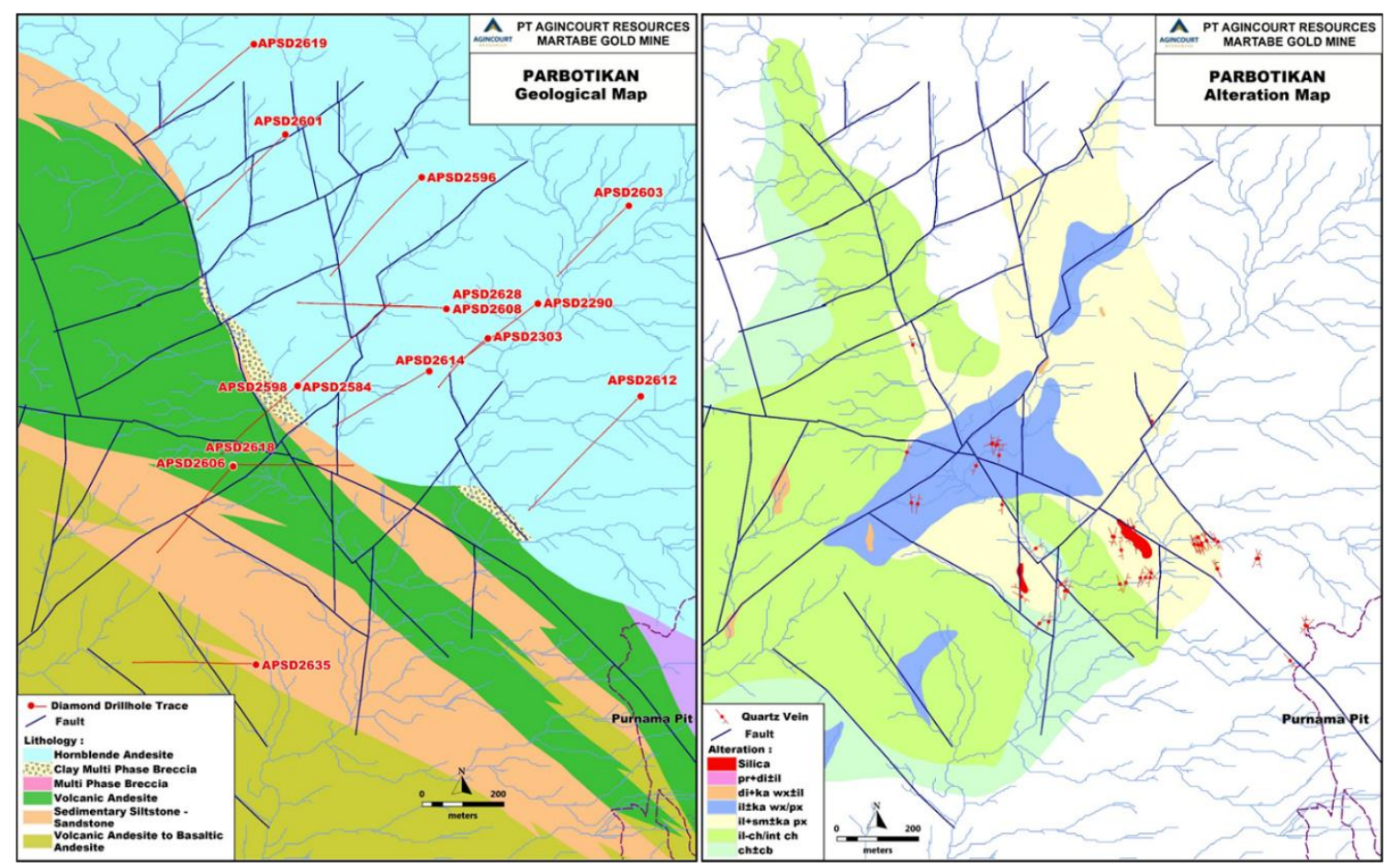

Gambar 9. Peta geologi dan alterasi daerah prospek Parbotikan.

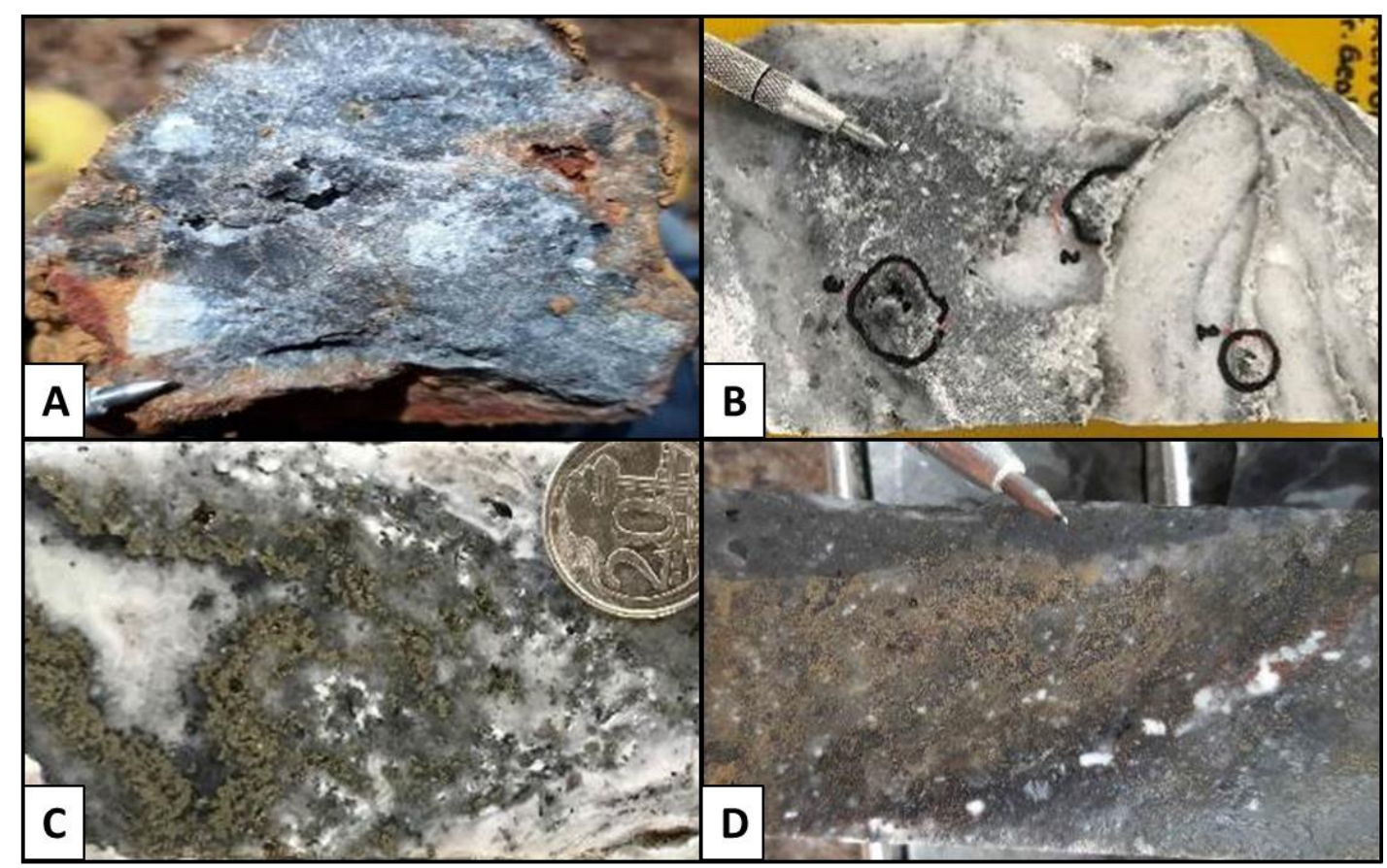

Gambar 10. Mineralisasi yang berkembang pada daerah kajian; (A) urat kuarsa berasosiasi dengan pirit-galena-sfalerit-kovelit; (B) urat kuarsa berasosiasi dengan pirit-galena-sfalerit; (C) urat kuarsa berasosiasi dengan pirit-tenantit; (D) urat kuarsa berasosiasi dengan sfalerit-galenapirit-tenantit-tetrahidrit.

Hasil pengeboran memperlihatkan bahwa urat kuarsa masih dijumpai kemenerusannya hingga ke bawah permukaan dan berasosiasi dengan struktur geologi berupa patahan. Adanya patahan ini menyebabkan terbentuknya zona lemah pada batuan sehingga berfungsi sebagai jalur naiknya 
larutan hidrotermal. Hal ini menyebabkan alterasi yang berkembang lebih dikontrol oleh struktur geologi dibandingan dikontrol oleh litologi.

Urat kuarsa dijumpai dengan ketebalan antara kurang dari $1 \mathrm{~cm}$ sampai dengan $40 \mathrm{~cm}$, dan hadir di unit batuan andesit vulkanik, dasit vulkanik, breksi freatomagmatik, dan batulanau. Urat kuarsa ini lebih mudah diidentifikasi pada batuan inti pengeboran dan umumnya berkembang baik pada kedalaman 50-100 meter dibawah permukaan. Urat kuarsa dicirikan oleh tekstur kristalin halus sampai sangat halus, dan tekstur dogteeth, serta mineral sulfida yang mengisi rongga kosong. Kehadiran urat kuarsa ini dikontrol oleh struktur geologi berupa patahan yang umumnya berarah hampir utara-selatan hingga timurlaut-baratdaya.

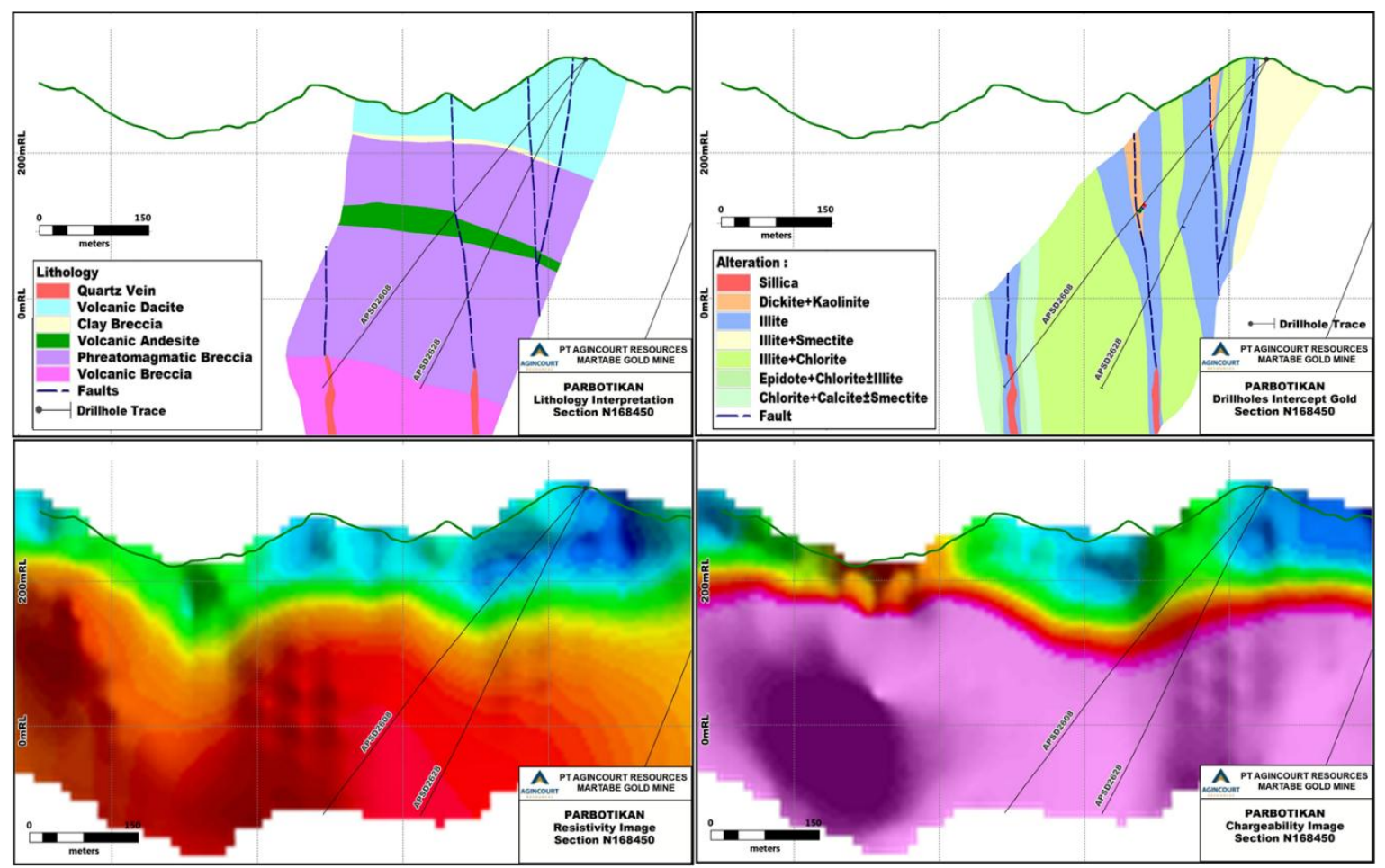

Gambar 11. Penampang interpretasi geologi dan interpretasi alterasi berdasakan data pengeboran eksplorasi, serta hasil survei IP konvensional menampilkan data resitivitas dan chargeabilitas pada sayatan profil

Analisis laboratorium atas kandungan mineral logam pada urat-urat kuarsa yang dijumpai pada batuan inti pengeboran umumnya memberikan hasil yang kurang signifikan yaitu $<0.5 \mathrm{~g} / \mathrm{t}$ emas. Untuk mineral logam berat seperti tembaga, antimon, timbal, dan seng memberikan nilai yang cukup signifikan dan pada beberapa conto juga berasosiasi dengan kadar bismut, tellurium, dan molibdenum yang cukup tinggi. Hadirnya mineral-mineral logam berat tersebut dengan kadar yang cukup signifikan dapat mencirikan sistem cebakan emas dalam.

\section{C.3. Komparasi Hasil Pengeboran dengan Data IP Konvensional}

Nilai chargeabilitas yang tinggi pada penampang geologi menandakan bahwa batuan yang ada mengandung mineral sulfida yang tinggi, dimana batuan hasil pengoborannya umumnya berasosiasi dengan pirit. Pada beberapa urat kuarsa juga berasosiasi dengan mineral sulfida logam berat yaitu sfalerit-galena-pirit-tenantit-tetrahidrit. Nilai resistivitas yang tinggi menandakan bahwa batuan masih cukup kompak atau intensitas ubahan mineral alterasinya masih rendah, hal ini ditandai dengan hadirnya mineral yang terbentuk pada suhu rendah salah satunya yaitu klorit. 


\section{KESIMPULAN}

Berdasarkan hasil pemetaan geologi permukaan, survei IP dan pengeboran eksplorasi terindikasi bahwa alterasi dan mineralisasi yang berkembang di wilayah prospek Parbotikan adalah sebagai target "cebakan emas dalam". Untuk jenis mineral endapan epitermal dangkal (emas-perak) tidak cocok untuk kondisi geologi daerah kajian sehingga dapat disimpulkan bahwa lokasi daerah kajian secara geologi belum ekonomis.

Untuk membuktikan adanya mineralisasi dengan target dalam $(>500 \mathrm{~m})$ perlu dilakukan pengeboran batuan inti dalam. Untuk membantu target tesebut maka diperlukan data tambahan yaitu berupa data geofiska survei 3D IP, dimana data geofisika yang diperoleh bisa mencapai kedalaman $1000 \mathrm{~m}$. Penambahan titik bor dalam akan direncanakan dan ditindaklanjuti setelah mendapatkan hasil interpretasi dari data geofisika 3D IP yang saat ini sedang berlangsung.

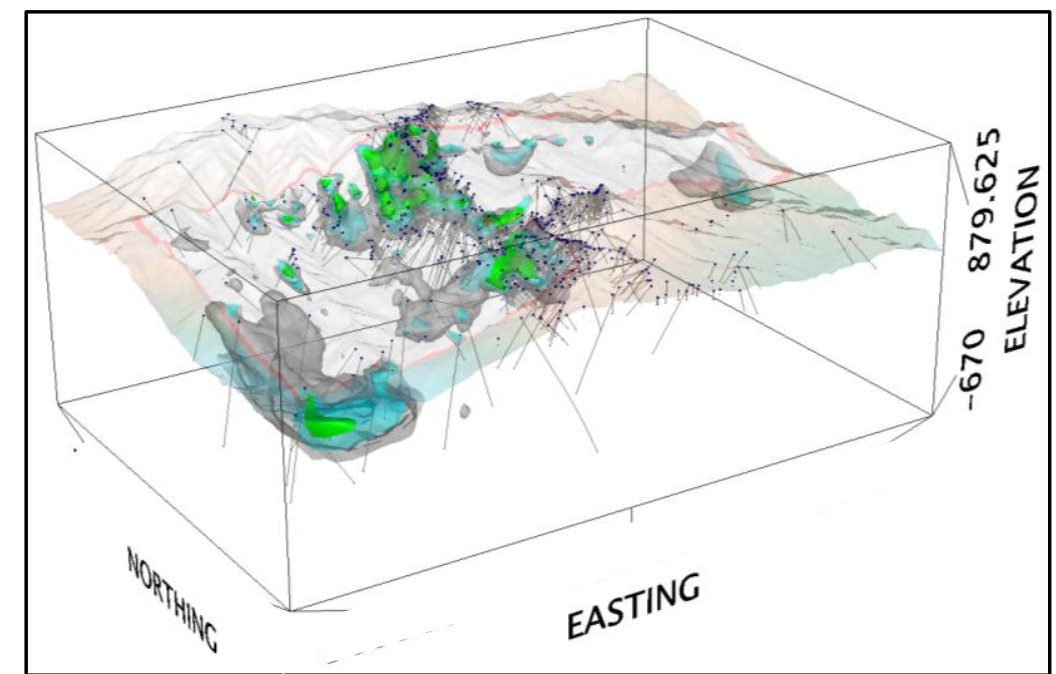

Gambar 12. Hasil sementara (preliminary results) pemodelan 3D IP pada daerah eksplorasi Martabe.

Hasil survei 3D IP dan pengeboran dalam diharapkan dapat dipergunakan untuk memverifikasi dan membantu dalam mengambil keputusan akan beberapa lokasi yang direncanakan sudah sesuai dari sisi ekonomi, geologi dan geoteknik untuk penempatan tailing dengan metode kajian terpisah. Penggunaan teknologi terkini untuk mendapatkan data seoptimal mungkin dan hasilnya untuk menunjang kegiatan eksplorasi, perencanaan, dan pertambangan adalah salah satu "action" kebijaksanaan yang diambil oleh PT. Agincourt Resources. Peningkatan akan kemampuan Sumber Daya Manusia (SDM) dalam menjalankan kegiatan survei 3D IP dan penganalisaan data juga menjadi target Human Capital (pengetahuan, keterampilan, dan kemampuan yang dapat digunakan untuk menghasilkan layanan profesional) sehingga keputusan strategis untuk hasil akhir survei 3D IP dan pengeboran dalam bisa diambil kemudian berdasarkan pertimbangan optimal.

\section{DAFTAR PUSTAKA}

Exploration Geologist, Hasil Survei IP (2009), Laporan Internal - Tidak Dipubilkasikan, PT. Agincourt Resources, Tambang Emas Martabe.

Exploration Geologist, Hasil Pemodelan Survei IP (2019), Laporan Internal - Tidak Dipubilkasikan, PT. Agincourt Resources, Tambang Emas Martabe.

Kuswanto, A., Garinas, W., Zikri, S., Proses Pengambilan data dan Pemanfaatan Geolistrik Metode 4-D untuk Pemetaan Geologi Bawah Permukaan (2018), Majalah Ilmiah Pengkajian Industri, Vol 12 No.1, 47-56. 
Pezzot, E. Trent, 3D Induced Polarization and Magnetometer Surveys on the Greenstone Project (2008), S.J.V. Consultants Ltd, Kamloops Mining Division, British Columbia, Canada.

Satya, M., Silalahi, B., Fransiskus, E., Parbotikan Final Report (2019), Laporan Internal - Tidak Dipublikasikan, PT. Agincourt Resources, Tambang Emas Martabe.

SubSurface Surveys \& Associates, Inc., 2004, Geophysical Methods \& Applications, data diperoleh dari situs internet: http://subsurfacesurveys.com/pdf/Methods.pdf. Diunduh pada tanggal 6 Juli 2019.

White, R.M.S., Collins, S., Loke, M.H., Resistivity and IP arrays, optimised for data collection and inversion (2003), Exploration Geophysics Vol 34 No.4, 229-232 